This is the author's final, peer-reviewed manuscript as accepted for publication. The publisher-formatted version may be available through the publisher's web site or your institution's library.

\title{
Questions of travel
}

Elizabeth Dodd

\section{How to cite this manuscript}

If you make reference to this version of the manuscript, use the following information:

Dodd, E. (2012). Questions of travel. Retrieved from http://krex.ksu.edu

\section{Published Version Information}

Citation: Dodd, E. (2012). Questions of travel. Interdisciplinary Studies in Literature and Environment, 19(1), 163-175.

Copyright: ( The Author(s) 2012. Published by Oxford University Press on behalf of the Association for the Study of Literature and Environment.

Digital Object Identifier (DOI): doi:10.1093/isle/iss005

Publisher's Link: http://isle.oxfordjournals.org/content/19/1/163.full 
Questions of Travel

Januaries, Nature greets our eyes

exactly as she must have greeted theirs:

every square inch filling with foliage...

(Elizabeth Bishop, Collected Poems 91)

Midlife, nearly a decade later in my own than Elizabeth Bishop was in that remarkable year when she entered the Southern Hemisphere as the "chronically displaced person, always just removed from the wholeness, meaning, comfort, and security that we all seek in our lives” whom her biographer, Brett Millier, describes (xi), I’m going to Brazil. I've copied a few choice lines in my journal, words to consider on the trip. And I think of her poised on the edge of her defining journey, her bags (or trunks, probably) packed with I-can't-quite-imagine-what specific clothes or books, heading for as-yet unglimpsed connections with rivers, a continent, love and loss.

It's true, I think: Bishop was often adrift and the poems exhale loneliness which neither adventure nor a passionate interest in surroundings can ever quite dispel. But it’s that interest in the world, especially the world witnessed, the world-as-seen, which draws us to her poetry. The view of boats tossed up on the shore from rough water and weather (oh, time and tide), she likens in a poem to "torn-open, unanswered letters." Thus, in her mid-February scene, "[t]he bight is littered with old correspondences” (60). The image, as I re-read it now, seems freshly poignant. There it is, the recognition of "[a]ll the untidy activity" that is existence, human or otherwise, here registered "awful but cheerful” (61). There they are, the ripped envelopes, such slender vessels to carry the weight of thoughts. And this time, no answer — so much of the poem's loneliness resides within that poignant 
and unspecified implied silence. Like so many writers before this "information age," she was a prolific correspondent; I frequently wonder, now, what is happening to the epistolary use of language to span time and distance. We "text"; we "chat"; we "post." Will we keep any of these communications, take them out to re-read years later, trying to put ourselves back in those earlier moments? Or will that kind of reflection disappear from the mind's landscape? Imagine the beach emptied altogether, impersonal, inanimate silence.

In 1951 her ship “crossed the Equator some time in the night” and Bishop sat out on the deck in the wee hours before dawn, watching " $1 / 2$ a moon—masses of soft, oilylooking stars” in “a damp wind” (Millier 240). Nearly a week later the passengers arrived at Santos, a port city lying just beyond the line of the Tropics of Capricorn, corresponding, I think as I gaze at a map, to a northern hemisphere latitude somewhere near Mazatlán, Mexico. It seems helpful to reach for comparison, to calibrate place from the perspective I already have as a life-long dweller in variations of north. North \& South, she titled her first book, almost prophetically, since the eastern-seaboard world of her emotional imagination (Nova Scotia to New England) and the geography of her adult residences (New York to Florida) were still all cupped beneath the stars of a single hemisphere. Only later would she venture even farther south, to the other side of the world.

From Santos, Bishop traveled by train to Rio de Janeiro, comparing grass-covered hills to "domes of St. Peters" and commenting how they held the same "bright but sparse look of Mexican grass” (Millier 242). “Impractical,” she decided the scenery was. "But I 
felt from the minute I opened my eyes that if I'd been dumped there from the sky I'd know right away I could be in no place but South America” (Millier 242).

"Dumped from the sky" is not a bad way to describe contemporary air travel. Never instantaneous, in the geography of airline hubs, each a holding-pen for the captive travelers harried by layover or delay. This time my travel is two legs of international flight—Miami to Panama, Panama to Manaus—-taking the better part of the day’s sunlit hours before arrival in the capital of Amazonas, a city of some two million people crammed onto the north bank of the great river.

As I travel, in the Gulf of Mexico the BP inundation of oil continues unabated, inaccurately tallied, persistently and erroneously called a "spill," as if the quantity were fixed though the fouling plumes keep roiling upward. But as we fly toward Panama, cloud cover obscures the view from the plane, though I try to see what's happening below. Why, I keep wondering, does nobody call it an oil flood? It is certainly a disaster.

But then over land, the plane glides through clearer skies, and the mid-day sunlight shines down on mile after mile of roadless jungle. Over what must be Colombia and then Brazil, unbroken tree cover, looking bumpy in texture like some fantastic Berber carpet. Hundreds of miles of chlorophyll green. No roads. Even at an altitude of 35,000 feet, we'd surely see some hint of them; and then, when a river comes into view—look at the size of it—s-curving its dark current through the surrounding green, still I see no roads. Some two million square miles of closed canopy forest still leaf into the deciduous lung of Amazon region (Soares-Filho 2004), even now, after the gash and flame of the 
late $20^{\text {th }}$ century. After yesterday's flights across the Midwest’s agricultural patchwork and the night-time metastasis of lights that is Miami, it’s exhilarating to see so much jungle, to feel the plane so deceptively insignificant, too small to cast even a shadow below.

Once landed in Manaus—where those two million people hang laundry to flap from the two- and three-story houses I want to call tenements, gather in streetside restaurants beneath highrise apartments downtown, cram plastic chairs into the fin-desiecle opera-house plaza to watch a free performance of Carlos Gomes' The Slave-here, there are roads. For the most part they're paved in familiar asphalt but bordered by very steep curbs, a precipitous feature which I come to understand the morning of a particularly percussive downpour, when the water foams around the tires of the parked cars, washes up across the sidewalk until, the cloudburst over, merchants all come out squeegee the sidewalks clear, sweeping the trash back into the street. In the coming days, I'll even visit a lab where undergraduate students explain their research using different paving compounds, how they're at work to design asphalt with great plasticity for such a wet-clay land.

But once out of the city—not so many. One, BR 174, heads north, all the way to Venezuela, I'm told, though the bus we ride (windows open in the morning heat) goes only as far north as a cacao plantation, half an hour from town. (“Don’t use the word cocoa the way we say it in English,” Bishop cautioned Robert Lowell before he came for a trip to give lectures and readings; “- -it means merde.” Could she not even bring herself to say—or write—shit in English?) (Words 397). Across the river and connected by ferry, another road, BR 319, heads south towards Bolivia. Yet what I see from the air is a 
beautiful blur of green punctuated by the inland lakes that curve, like tildes, like parentheses, around the flooded-forest margins of those equatorial rivers. Later, on the rivers themselves (the Rio Negro, the Ariaù, the Salimões), I watch boats. Ferries, where the few cars waiting to board mass along the dock, crowding to be first. Fishing boats. Dinghies or skiffs scooting along the river's wooded shore. Once, a canoe, slipping beneath the trees.

Away from—what is it? Shore? The bank?—dolphins sometimes swim near the boat; a sloth, once, clutching a tree branch in its talon-like claws, seems to watch as we float below.

*

Really, I could never have envisioned so much inland water.

In an afternoon lecture, I scrawled a few notes. At the Meeting of the Waters, where the two great currents that descend from the west join to form the Amazon itself, some 3.8 trillion cubic meters of water pass through each year. The rainfall throughout the basin totals some 15 trillion cubic meters. I wrote these figures in my notebook, tried later to figure what such numbers could mean, but of course I couldn't. Trillion: a million millions. 3.8 trillion cubic meters: 23,901,280,165,145 petroleum barrels' worth. Such numbers hold no meaning for to me, so I poked around, seeking some kind of comparison. I plugged in a recent estimate of the United States' annual use of oil: 7,548,200,000 barrels. Well, thank goodness, we don't burn an Amazon River's worth of oil every year, but we do use nearly half that consumed by the eight nations with the greatest oil use. Number eight, I learned, is Brazil. 
Where the waters meet, boats of tourists gather, motoring along the scalloped border. Ours tools along gently, the tiny back deck slick with the morning's rain until someone comes with a towel to mop it down; a few vigorous strokes and then he thrusts the fabric in the boat's wake, rinsing it clean. So now I've glimpsed a few hours' worth of that trillionatical river at its end-of-rainy season height, the Rio Negro’s current against the milky Solimões in a handsome pattern I hadn’t expected—exactly like, I realize, the curving lines of tile that pave the plaza by the Opera House, exactly like the tilde in the plaza’s name, Saõ Sebastien. That’s how Bishop would have phrased things—“exactly like.” In the poems, similes wink from the page; in the letters, she underlines for emphasis. Breeze flowing through the open windows, the single hammock rocking in the boat's motion, I think the land seems minuscule, low bluffs, sandy crescents of beach. Clouds rise in great cumulous stacks in the distance with occasional lightning. Another day, I lie in the hammock stretched across the tiny hotel balcony a few feet above the stained riverwater. When the storm finally passes, a flock of parrots wheel back in with their strangely digital-sounding clatter of calls.

Returned to the States for a brief visit in 1957, Bishop wrote to Robert Lowell that she was “depressed” by the northern landscape, “I don’t know why_I think it’s mostly automobiles makes me feel so hopeless [about the United States]. "Surely," she mused, “no country has ever been so filthy rich and so hideously uncomfortable at the same time” (Millier 292).

"We leave Santos at once; / we are driving to the interior,” she concludes the opening poem in Questions of Travel. As if it all waits just beyond the dock: the whole of the 
continent unfolding, dense and green and exhilaratingly vast, all somehow present in the creamy white space of the paper stock, before you turn the page. Like, though she wouldn't have thought so, the dislocating swoop when you type the destination into Google Earth. How was it, really, I wonder, after she stepped off the freighter, one of just nine passengers on the ship that had left New York in November? Only two disembarked, the other (also an American woman) to stay nearby in Saõ Paulo, and shortly thereafter Bishop took a train to Rio de Janeiro, some three hundred and fifty miles up the coast.

"We are driving to the interior.” In the line’s simplicity, such a chord of connotation. The poem has been rocking back and forth, anticipation and perception, that marvelous bobbing sensation you feel on almost-calm water. "Finish your breakfast," it's soon time to leave. At customs, the staff "will speak English, we hope." And so the simple declarative verbs suggest, despite their surface mood of present tense, impending action, the moment filled with the promise of more moments to come. The published poem is dated "January, 1952" though the actual date of her arrival at Santos was November.

Turn the page in the book, and you're plunged into another poem, another January, this one in 1502, and, I realize now, you must be gazing ahead through a curtain of rainfall, the rainy season having just begun in December. Despite presentation of a "tapestried landscape," as if the land is a completed artifact in the past perfect tense, beneath the objectifying gaze of both the colonizing Portuguese and the contemporary travelers, Bishop’s actual language dismantles her own framing metaphor. This is no static tapestry, "embroidered" into "hanging fabric" that is "fresh as if just finished" moments before we (any of us) arrived to look. In the opening lines the action remains 
unfinished, "every square inch filling in with foliage," insisting on process, the ecological energy of the place. "I finally had to do something with the cliché about the landscape looking like a tapestry, I suppose,” she later mused (Words 310).

"We are driving to the interior." How exhilarating, the way time and place collapse in the sudden ambiguity of a Latinate noun—not "inland," no, but a destination psychological as well as physical. Like the giant lilypads I know she saw along the Amazon years later, and that I've seen now, too, touching the green, buoyant surface with my bare toes; I could float here in the language all afternoon, as I imagine she must have, testing our words for nuance and surprise. Place and time: Nature which "greets our eyes / exactly as she must have greeted theirs.” Of course, this was not strictly true, even in 1952. Four centuries of plunder had already taken toll on the rainforest, though Bishop is more interested here in the cultural destruction of the indigenous peoples, so appalling one can hardly bear to look straight on, the "old dream of wealth and luxury" that fueled the engine of colonialism. Why do I write in the past tense? That fuels what we now call globalism, I could just as easily say.

The great freshwater turtles—adults could weigh half again as much as I do—-that once populated the rivers in the millions had suffered the usual $19^{\text {th }}$ century mass slaughter of commercially useful species. When Alexander von Humboldt arrived in the Amazon in the early nineteenth century, he saw Franciscan missionaries supervising the exhaustive plunder of every nest on a beach; oil from the eggs was bottled for export to Europe, to light chandeliers and to stock fashionable kitchens. He calculated that each year thirty-three million eggs must have been destroyed (Hemming 129). Even so, at the start of the rubber boom in the 1870s the enormous animals still emerged from the river 
in great dry-season spectacles of mating and egg-laying. "As far as the eye can see, which hereabouts run straight for some six or seven miles, were continuous rows of turtles at the water's edge ... many thousands must have collected together,” wrote a British railway engineer (Hemming 127). By the mid-twentieth century the farmers were thoroughly routed by disease, enslavement, and despair; the turtles (Podocnemis expansa) had perilously declined.

I never saw turtles in the wild. Did she? There's no hint of it in the poems. Giant toad, giant snail, a morpho butterfly, these all make appearances. The river dolphins, gray and pink. Surely, I think, if she'd seen them, she'd have left word.

But so far my thoughts have been following rivers, for centuries the only avenues of entrance into the interior. I think Bishop must have reached Saõ Paulo by car—she was then traveling with some ex-patriate Americans. But from Saõ Paulo up to Rio where her own friends awaited her, she traveled by train. Car travel was still a new and very partial addition to the geography of access. In a prose piece, Bishop writes of a day trip outside Belém, where her host, a "shy young poet," conducts her and a friend to Vigia, a village sixty miles or so distant, with a spectacular church. They leave town together in the young poet’s car, which "was on its last legs; it had broken down twice just getting us around Belém the day before” (Collected Prose 111). On their way out of town they pass both "a dead-looking railroad yard ... the end of the line" and the drying, wilting garlands that had been recently strung up "to celebrate the opening of the new highway to Brasilia” (112). As they drive by she observes that the highway isn’t paved yet, but “the very thought of this new road to the capital had cheered up all of Belém considerably” (112). 
The story—or is it really an essay? She seems to have changed only the namesthe piece was never published during her lifetime, and reading it, I see passages I am certain she would have changed, bits of the first draft serving to peg down the rough narrative, from which she had yet to tease out all the nuance and dimension that color her published work. The rhythms of syntactic simplicity last just a few beats longer than I have grown to hear as Bishop's natural voice: I'd expect, there, a break from the prevailing sentence brevity, a shift to something more expansive. I re-read the piece compulsively, listening for hints of where she surely would have returned to revise. The narrative recounts a day's journey through an economically ragged locale, where, despite implied hunger, hospitality remains dressed in good manners. A traveler, far wealthier than her host, she remains uneasy in her skin and, I think, ultimately uncertain about what she has seen. One revelation after another, and whatever will ultimately connect them is still at play in the manuscript as Bishop left it.

At Manaus, you can see the pilings of an unfinished bridge crossing the Rio Negro. I watch it from the boat we take upstream to our hotel in the várzea, the flooded forest at the mouth of the Ariaù. (Aria, I learn, is a local word for a kind of wild potato endemic to the riverbanks. So many embouchures, think, little place-names like islands dotting the map.) As far as I can tell, scanning with binoculars, there's no work going on at the construction site. When I ask the men in the boat, there is laughter.

"They ran out of money!"

“They want to have it completed by 2014, in time for the World Cup. They’d better hurry!” 
I don't know what to make of this exchange. Meanwhile our boat, with the region's iconic jaguar painted on the side, cruises past both floating houses and highrises.

The Manaus- Iranduba Bridge will connect the north bank with the south, but yet another, larger structure would have to be built across the sister-river, the Salimões, for the presumed goal of reaching the state of Rôndonia, more than 500 miles to the south. And the 319 highway, currently in such poor repair it is impassible in places, would need reconstruction; the hiatus in both development and fragmentation that this portion of the rainforest has enjoyed in recent years would come to an end. Published press reports emphasize the local importance of the bridge: eliminating the need for ferries in order for farmers to bring crops into the city; facilitating commuting by regional university students (most of whom do not live in campus housing, but with relatives); advancing ecotourism. But I stumble on a private posting in an online forum that rings true, beyond the brief stumbling of typos.

"The bridge would carry a pipeline too. 300km West of Manaus there is a massive hydrocarbon basin (oil+gas) whose development barely started. Drill, baby, drill 9 and then build a pipeline to haul it $3000 \mathrm{~km}$ away.” The poster, who calls himself Suburbanist, includes a little manifesto along with his photograph: "We need transport that is comprehensible, flexible, passenger-focused, bear few if any legacy problems, is interchangeable and allows for segregation of infrastructure and operation ownership and costs, allowing massive private investments to pour in, spurring innovation and empowering people in the process. It's called personal automobile or car. Just don't say it loud to appease environwackos and the transit brigade. :)” 
Until now, I wasn’t primed to notice the specific modes of travel in Bishop's work; instead, probably like most readers, I paid attention to the arrivals—what is seen, and how the act of seeing shapes the seer as well as the object under view. But of course, to see something new, you have to actually get there. Bishop didn't travel as widely in Brazil as she would have liked to, and though she spoke frequently of wanting to write travel pieces, the 1962 Life World Library publication, Brazil, was her most extended such project and a terrible frustration to her. In a letter sent to her Aunt Grace when she first agreed to the project, she worried, "that kind of writing is hard for me to do and I have to cover the whole country—history, economics, geography, arts, sports— everything, even if superficially" (Letters 399) and soon she found herself "having a hideous time writing the thing [...] It is really more like manufacturing synthetic whipped cream out of the by-products of a plastic factory than anything remotely connected with writing” (399-400). She complained, "they keep putting their favorite clichés right back in again and then sending me the proofs for my approval” (Letters 404).

"Imagine a Brazil without a bird, beast, or flower in it," she raged later to the poet May Swenson. "I insisted on at least one page of animal pictures [...] -I wrote 2 Or 3 nice pages about NATURE $[\ldots]$ all that cut out $[\ldots]$-They are not interested in sloths, boa constrictors (one attacked a child in the city of Belém yesterday) ant-eaters, morfo butterflies, orchids— 4,000 varieties of fish, and so on...parasol ants, jaguars” (Millier 328). And to Robert Lowell, who had just sent her a postcard of Henri Rousseau's painting The Dream, she confided, "Your Rousseau postcard came at just the right minute. I was working on a chapter about naturalists, the jungle, etc. LIFE is getting 
nervous about this_-say they're more interested in people than animals” (Words 373). There is no such chapter in the published book.

The much-reviled editors with whom she battled were also interested in roads and railroads, commerce and export. The book contains one blurry, humid-looking full-page photograph where, near Manaus, "the Amazon pours into numerous channels to create vast swamps” (Brazil 34); the curves of the two stream channels seem to echo the highway image from a few pages earlier where "the sinuous Via Ancheta links the port of Santos with Saõ Paulo” (Brazil 24). Oh, I think—driving to the interior. Bishop’s own prose describes a "geographical handicap”: the rivers do not seem to lead to "vital cities," an odd grammatical implication that those "great and navigable” rivers somehow placed themselves inopportunely on the human landscape (Brazil 28). Or is this one of the many places she despaired of, where her own language disappears beneath the slick, glossy tone favoring “development”?

Dirt roads or no, Bishop bought a car, explaining to Robert Lowell, “I made enough on a story in The New Yorker to get it—a slightly second-hand MG, almost my favorite car, black, with red leather. It zooms up the mountains with the cut-out open, but really I only like speedy looking cars that I can drive very slowly” (Words 147). "I don’t think I'd ever drive in Rio,” she mused. “It's all done by some other process there, anyway, not 'driving' at all, I'm sure. (The head of the traffic system there just committed suicide and they decided he could have a Christian burial anyway, I suspect out of sympathy) but I’ll get my license up here in Petrópolis, which isn’t so bad” (Words 155). 
When she made her way to the Amazon River, however, it was by plane. Like me, she flew into Manaus, then took a boat downstream to Santarém. Preparing for the trip, she worried about mosquitoes; a friend counseled wearing "cotton stockings and gloves” (Words 309). I doused trousers and shirts with Permethrin and, on the e-mailed advice of a friend, took Malarone rather than Mefloquine as an antimalarial. Her trip took place in mid-February; the rainy season was well underway, but the river wouldn’t yet have swelled and swamped to its fullest flood stage, as it had when I arrived in late May. She'd received a pair of binoculars as a gift from May Swenson just three months before, and I imagine her standing on the deck, examining the trees along the bank: the kapok, or silk-cotton, those enormous, broad-crowned monarchs of the riparian rainforest; palms buzzing with insects; strangler figs sending down roots in a wicker-like weave. I imagine her scanning the banks for the occasional sandy beach, or gazing upstream when one of the innumerable tributaries joins the big river.

"I want to take a long and very tough trip up-river next time, into Ecuador and Peru—it can be done," she later wrote wistfully (Letters 386). But her partner Lota "refuses to have anything to do with anything Brazilian or 'primitive,"” she complained, and here's some of the loneliness surfacing again. "She says she wants something more civilized rather than less when she goes traveling” (Words 318). The distance across the continent, river-spanned, is lit with purposeful desire ("it can be done") while that between the ideal life and the one that's lived remains unbridgeable. Lonely in her wanderlust, Bishop dreams herself elsewhere. “[G]eographic curiosity leads me on and on and I can't stop. Last night I dreamed there was a narrow road that began at Tierra del Fuego and went straight north, and I had started to walk it, quite cheerfully. A large 
primitive stone coffin was being carried on muleback alongside of me, ready for me when I gave out. The mule driver had a toothache (I can’t understand that part)” (Letters 386).

In “A Trip to Vigia,” Bishop invests the drive along an unpaved road in rural countryside with a journey toward delicate, social intimacy, the moment when the travelers from Rio shift from formal to informal linguistic address with their Brazilian host. The car breaks down once, is coaxed back into motion, then breaks down again. The host's friend, who has come along as the mechanic for this excursion, labors under the hood. "Suddenly the rain came down hard, great white lashings. The bushes crouched and the gravel danced.” Brought into even closer camaraderie by the intensity of the cloudburst, the travelers experience a concordance between the little human world and the larger one outside the imperfect conveyance of the car, and suddenly their grammar shifts to an intimate você: “the mystic moment was past,” Bishop muses (Prose 114). I'm reminded of the moment in another poem, where bus passengers half-doze through a night-time drive in Nova Scotia. The human world within the bus; the outer world of dark and forest until the bus stops suddenly, a moose in the road.

In "The Moose" the harmonic moment is brief, a "sweet sensation of joy" that rapidly fades, the moose left behind in the road, even its scent "dim” while the bus is filled with "an acrid / smell of gasoline” (Poems 173). The arrival at Vigia remains ambiguous: the church is lovely, but in trying to admire it the tourists climb on a wall to take a photograph and draw a small crowd, "all looking scandalized" (Prose 118). The sacristan hands them the bones of a priest who died just a few years ago and Bishop 
describes "trying to hand the skull back" while the man rattles on, speaking of values she can't quite glimpse, until they are able at last to step back outdoors where "shafts of long golden beams fell through the thunderclouds" so that "Nature was providing all the baroque grandeur the place lacked" (Prose 119). The story does not end there, however; the narrative presses on through the gathering dark. This time the animal in the road is a zebu, one of several oxen glimpsed in this agricultural economy where bare toes grip the dirt. "We almost hit him, a high bony gray wall across the road” (Prose 120).

By now I've convinced myself. Bishop must not have seen the giant turtles. And this is my own regret for this trip, the missed opportunity. I have glimpsed some tropical wonders. Once, a white-patched king vulture soaring by red-clay cliffs. The distant auditory blur of howler monkeys, roaring at dawn. Leaf-cutter ants carrying miniature snippets of foliage like weathervanes or sails, a steady moving cordage of them stretched across the terra firme trail. Horned screamers the size of turkeys, their single quills protruding from their foreheads as if, moments before, one could have seen the bird's most recent thought suspended there. Caymans, both small things the size of dachshunds, hanging still and dark in the tree-dappled water, and a single leviathan that kept satisfied, toothy watch near the hotel kitchen. Feather-crested, blue-faced hoatzins, looking as if they'd just stepped out of the fern-tree shadows of another era. All these I've seen, plus dusk on the river when the near-equatorial sun dropped straight down, un-angled in descent, and lightning flash-throbbed in the distance, linking cloud with flooded earth, while the tiny open boat sped back toward dock. 
What is it, this desire to set eyes on the actual things we've only read about, to look across whatever distance separates one's self from the myriad other selves, to take in all those minute, spectral disturbances of light that register the world of matter? I'm greedy for seeing. It seems I'm primed, through whatever cascades of chemistry incline the body towards desire, for presence, attendance, light reaching the retina, sun pinking my skin.

I wish I'd seen those ancient turtles. They seem like symbols of patience, of persistence, as if they've swum all the way from the Triassic, where fossils of turtles make their first carapaced appearance in sedimentary records. Podocnemis expansa eat only in the rainy season, when the rivers float them into the forests to browse on tree leaves and fruit. When the waters drop, they fast through the ensuing dry months. Sometime in September, they leave the river for sandbar beaches, heap sand over dozens of leathery eggs and haul themselves back to the water, back to the slow, metabolic pulse of river and rain while sun heats the beach. I wish I had seen one.

In the day's ponderous heat I walked in the flooded forest, along broken boardwalks and a pocked veranda, one corner of the metal shade roof flapping where it had been torn from a flood-stained pillar. Wattled jacanas stalked the swampy edge of what my map called the "lake," folding their wings with exactly the same flourish as upland sandpipers already nesting back home, however many thousands of miles away. The river current was so stalled and slow that petals knocked loose by the parrots feeding overhead stayed where they'd fallen, as long as I cared to watch. As if they might float forever. 
Today, I read a list serve post about rare sea turtles killed by the Deepwater Horizon disaster. These aren’t, of course, the freshwater giants I didn’t see along the Amazon. They're salt water dwellers, mostly Kemp’s Ridleys (Lepidochelys kempii), and I’ve never seen them, either, though I kept watch once along a North Carolina beach at the time the eggs might hatch (they didn’t, not till some nights later). The story steadily worsens, from descriptions of sick turtles puking up oil, to tallies of beached carcasses. And here's an interview with a rescue worker describing the turtles he couldn't get to being set afire, part of the "cleanup” effort to burn away the deluge of crude. Encircled by booms, already sickened by the carboniferous sludge, the animals blaze and char. "I am sorry to forward this; I feel like I'm Kurtz in Heart of Darkness,” the poster to the list serve wrote (Plevin).

“Coming down on the boat I started reading Conrad,” Bishop wrote to Lowell after returning from a visit to New York in 1957. "We actually did go through the Doldrums — a day of them. The water absolutely slick and flat and the flying fish making sprays of long scratches across it, exactly like finger-nail scratches. Aruba is a little helllike island, very strange. [..] it's set in miles of oil slicks and oil rainbows and black gouts of oil suspended in the water, crude oil—and Onassis' tankers on all sides, flying the flags of Switzerland, Panama, and Liberia” (Words 244-45).

As always, I realize, I've been seeking connection. This is the mind's accretive activity, seeking to sort the kaleidoscopic arrival of each sense impression by likeness, by kind. We search out our symbols; we pour our attention into each received image until we've filled it with the feeling of our recognition. "We never look at just one thing," wrote the art historian John Berger. "We are always looking at the relation between 
things and ourselves” (9). It gives us a sense of continuity, taking our place in the sequence of noticed moments that rise from one horizon and drop beneath the other. It allows us - is this really illusion? - the feeling of company, even from those we've never met. Bishop noted, late in life, that she was the last of the Bishops, like me a childless women who left memes, not genes, in the wake of her passing.

...Oh, tourist, is this how this country is going to answer you and your immodest demands for a different world, and a better life, and complete comprehension of both at last, and immediately... (Poems 89)

The flight north from Manaus left late in the day; by the time we left Panama, headed back towards Miami, the sun had set. Below, in the flight across the Gulf, was nothing but darkness. 


\section{Works Cited}

Berger, John. Ways of Seeing. London: Penguin Books, 1972.

Bishop, Elizabeth. Brazil. NY: Time, Inc., 1962.

---. The Collected Prose. NY: Farrar, Straus, Giroux, 1984.

---. The Complete Poems 1927-1979. NY: Farrar, Straus, Giroux, 1983.

---. Letters: Selected and Edited by Robert Giroux. NY: Farrar, Straus, Giroux, 1994.

---. Words in Air: The Complete Correspondence between Elizabeth Bishop and Robert

Lowell. Ed. Thomas Travisano with Saskia Hamilton. NY: Farrar, Straus, Giroux, 2008.

Ferreira, P.D. and P.T.A. Castro. "Nesting ecology of podocnemis expansa and podocnemis unifilis in the Javaés River, Brazil.” Brazilan Journal of Biology 70.1 (Feb. 2010): 85-94.

Hemming, John. Tree of Rivers: The Story of the Amazon. London: Thames and Hudson, 2008.

Millier, Brett C. Elizabeth Bishop: Life and the Memory of It. Berkeley: University of California Press, 1995.

Osava, Mario. “Bridge to Drive Urban Growth in Heart of Amazon.” May 26, 2010 (IPS) http://ipsnews.net/news Accessed 2 July 2010.

Plevin, Arlene. ASLE listserve post 1 July 2010.

Soares-Filho, Britaldo Silveira, et al. "Modeling conservation in the Amazon basin.” Nature 440: 520-523.

http://www.skyscrapercity.com/showthread Accessed 2 July 2010.

http://rawstory.com/rs/2010/0620/bp-burning-sea-turtles-alive/ Accessed 2 July 2010. 
http://www.nationmaster.com/graph/ene_oil_con-energy-oil-consumption Accessed 2 July 2010.

http://www.npr.org/templates/story/ Accessed 7/2/2010.

$\underline{\text { http://animals.nationalgeographic.com/animals/reptiles/kemps-ridley-sea-turtle.html }}$ Accessed 2 July 2010.

http://www.chron.com/disp/story.mpl/breaking/ Accessed 2 July 2010. 